\title{
Pengaruh Ukuran Partikel Biomasa Lignoselulosa pada Pembuatan Bioetanol dan Biobutanol : Tinjauan
}

\author{
The Influence of Lignocelulosic Biomass Particle Size on \\ Bioethanol and Biobutanol Production : A Review
}

\begin{abstract}
Syahrul Aiman
${ }^{1}$ Pusat Penelitian Kimia - LIPI, Kawasan PUSPIPTEK Serpong, Tangerang Selatan, Indonesia

Corresponding author: syah_aiman@yahoo.com
\end{abstract}

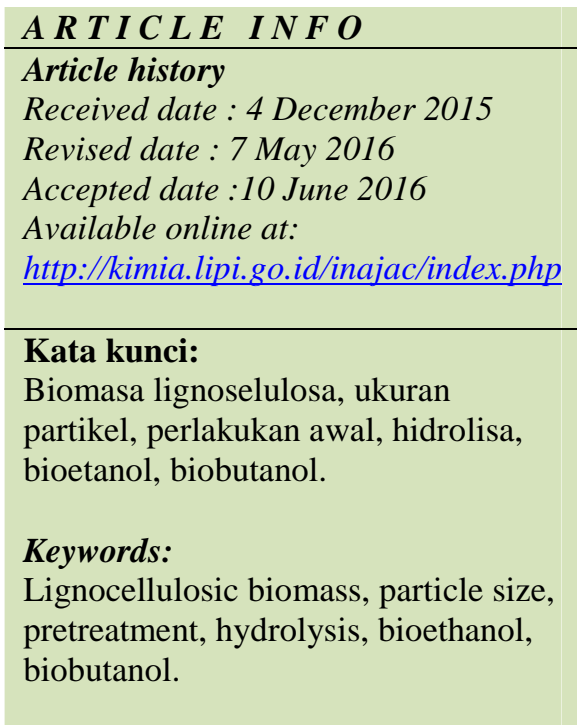

\section{Abstrak}

Bioetanol dan biobutanol dari biomasa lignoselulosa menjadi bahan bakar terbarukan yang sedang menarik perhatian banyak peneliti. Berbagai macam biomasa lignoselulosa yang berupa limbah pertanian, perkebunan, pengolahan hasil hutan, industri dan sampah kota telah diteliti untuk dikonversi menjadi alkokol. Berbagai parameter proses mempengaruhi efisiensi dan efektifitas proses konversi biomasa limbah organik tersebut menjadi alkohol. Salah satu parameter yang tidak banyak diperhatikan oleh peneliti di Indonesia adalah pengaruh ukuran partikel biomasa terhadap tingkat capaian proses konversi biomasa menjadi alkohol. Tinjauan ini ditujukan untuk melihat pengaruh ukuran partikel biomasa lignoselulosa terhadap pembuatan bioetanol dan biobutanol sebagai bahan bakar. Peninjauan dilakukan melalui kajian pustaka (desk study) dan ditambahkan dengan data primer hasil penelitian di Pusat Penelitian Kimia. Tinjauan ini memperlihatkan bahwa ukuran partikel biomasa mempengaruhi berat jenis unggun, viskositas campuran, luas permukaan spesifik yang kemudian menentukan luas permukaan kontak. Disamping itu, proses penggilingan mempengaruhi porositas partikel biomasa dan menurunkan kristalinitas selulosa. Semuanya akan mempengaruhi digestabilitas selulosa selama proses hirolisa. Meskipun pengaruh ukuran partikel pada proses konversi masih kontroversi, dan masih menjadi bahan kajian para peneliti, tetapi sebagian besar memperlihatkan bahwa semakin kecil ukuran partikel biomasa, sampai batas tertentu, akan meningkatkan proses hidrolisa selulosa menjadi gula sehingga meningkatkan jumlah alkohol yang dihasilkan. Selain mempengaruhi tingkat capaian konversi, ukuran partikel biomasa juga mempengaruhi biaya proses.

\section{Abstract}

Lignocellulosic bioethanol and biobutanol as renewable energy sources are become interesting matter by researchers. Various kind of lignocellulosic biomass wastes such as agriculture, forestry, plantation, industrial and municipal organic solid waste have been explored to be converted to the alcohol. Various process parameters influence efficiency and effectiveness of conversion process of biomass to the alcohol. This study is aimed to understand the effect of lignocelullosic biomas particle size on production of bioethanol and biobutanol as renewable energy sources. The review was conducted by combining desk study and a research at Research Center for Chemistry-LIPI. The study showed that particle size has been found to influence biomass bulk density, slurry viscosity, specific surface area and accessible surface area. In addition, the grinding process influences biomass porosity and decreases cellulose crystalinity. Finally, they would influence digestability of cellulose during the hydrolysis proses. Eventhough the influence of particle size to biomass conversion efficiency and effectiveness are still controvercy and are studied by research scientists, many results showed that decreasing particle size would enhance cellulose hydrolysis and increase the alcohol yield. The study also showed that biomass particle size not only influences the conversion to alcohol, but also cost of production.

(C) 2016 Indonesian Journal of Applied Chemistry. This is an open access article under the CC BY-NC-SA license.

"Pengaruh Ukuran Partikel Biomassa ...": S. Aiman 


\section{PENDAHULUAN}

Biomasa lignoselulosa terutama yang berasal dari limbah pertanian, perkebunan, pengolahan hasil hutan, dan sampah kota organik telah lama menjadi perhatian peneliti untuk dijadikan sebagai sumber energi terbarukan, baik untuk menghasilkan bahan bakar gas seperti gasbio, hidrogen, maupun bahan bakar cair seperti bioetanol dan biobutanol. Pemanfaatan biomasa lignoselulosa sebagai energi terbarukan, terutama alkohol, dimasa depan akan menjadi sumber energi terbarukan penting yang akan mengurangi ketergantungan dunia pada bahan bakar minyak $(\mathrm{BBM})^{[1-5]}$.

Di banyak Negara, termasuk di Indonesia, bioetanol telah digunakan menjadi bahan pencampur $\mathrm{BBM}^{[6]}$, oleh karena itu industri bioetanol terus berkembang. Dalam periode 2013 sampai 2014, telah berdiri enam buah industri bioetanol dari biomasa lignoselulosa berskala besar, dengan kapasitas produksi antara 30 sampai dengan 110 juta liter pertahun, dengan bahan baku sampah kota, jerami gandum, limbah jagung, atau berbagai limbah pertanian lainnya $^{[7]}$. Disamping itu terdapat 12 industri bioetanol besar lainnya yang sedang dalam pembangunan maupun sudah tahap uji coba $^{[8]}$. Namun demikian, beberapa sifat bioetanol yaitu bersifat higroskopis sehingga menyerap air dari udara yang akan mengakibatkan korosi, serta panas pembakaran yang jauh lebih rendah dibandingkan dengan BBM (Tabel 1), menyebabkan terbatasnya jumlah etanol untuk dicampur dengan BBM. Sifat-sifat ini menyebabkan jumlah etanol yang mungkin dicampur dengan BBM, tanpa mengubah mesin kendaraan, hanya sampai 10 $\%, \mathrm{E}-10^{[9]}$.

Pembuatan biobutanol untuk pencampur BBM dari biomasa lignoselulosa menjadi perhatian dalam dekade terakhir, karena kandungan energi yang lebih tinggi dari etanol, tidak higroskopis serta dapat dicampurkan dengan BBM dalam jumlah yang lebih banyak, sampai dengan $16 \%$, tanpa mengubah mesin kendaraan $^{[9,10]}$. Hal ini menyebabkan biobutanol, sebagai bahan bakar, jauh lebih prospektif dibandingkan bioetanol ${ }^{[11]}$.

Tabel 1. Perbandingan sifat etanol, butanol dan $\mathrm{BBM}^{[9,14]}$

\begin{tabular}{|c|c|c|c|}
\hline Parameter & Etanol & Butanol & $\begin{array}{c}\text { BBM } \\
(\text { Gasoline })\end{array}$ \\
\hline Formula kimia & $\mathrm{C}_{2} \mathrm{H}_{5} \mathrm{OH}$ & $\mathrm{C}_{4} \mathrm{H}_{9} \mathrm{OH}$ & $\begin{array}{c}\text { Variasi, } \mathrm{C}_{4} \\
{ }_{12} \mathrm{H}_{14-26}\end{array}$ \\
\hline $\begin{array}{l}\text { Titik Didih } \\
\left({ }^{\circ} \mathrm{C}\right)\end{array}$ & 78 & 118 & $30-215$ \\
\hline $\begin{array}{l}\text { Panas } \\
\text { Pembakaran } \\
(\mathrm{MJ} / \mathrm{kg}) \text {. }\end{array}$ & 26,8 & 32,5 & 42,9 \\
\hline $\begin{array}{l}\text { Panas } \\
\text { Penguapan } \\
\text { (MJ /kg). }\end{array}$ & 0,92 & 0,43 & 0,36 \\
\hline RON & $\begin{array}{c}106- \\
130\end{array}$ & 94 & 95 \\
\hline
\end{tabular}

Kelebihan lain dari butanol, dibandingkan dengan etanol, adalah tekanan uap yang lebih rendah yang menyebabkan volatilitas juga lebih rendah, dan lebih sedikit emisi. Sifat-sifat ini membuat biobutanol lebih mudah dicampurkan dengan $\mathrm{BBM}^{[11,12]}$. Pada tahun 2013, ASTM mengeluarkan ASTM D 7862 yang menjadi acuan dalam menelaah kualitas butanol sebagai campuran bahan bakar untuk kendaraan bermotor $^{[13]}$. Standar ini akan lebih mendukung penggunaan butanol sebagai bahan bakar kendaraan bermotor dimasa depan.

Biomasa lignoselulosa disusun oleh komponen utama hemiselulosa, selulosa dan lignin, dengan jumlah yang bervariasi tergantung jenis tanamannya. Contoh variasi ketiga komponen tersebut pada beberapa jenis tumbuhan dipublikasi di berbagai jurnal ${ }^{[6]}$. Salah satu tahap penting dalam proses konversi biomasa lignoselulosa menjadi alkohol adalah memutus molekul polisakarida, selulosa dan hemiselulosa, mengubah selulosa dan atau hemiselulosa yang tidak larut dalam air menjadi monosakarida berupa senyawa-senyawa gula yang larut seperti glukosa, silosa atau lainnya ${ }^{[15]}$. Selanjutnya, melalui proses fermentasi senyawa gula diubah menjadi alkohol.

Agar selulosa dan atau hemiselulosa dapat diubah menjadi senyawa gula, lignin harus dipisahkan terlebih dahulu. Lignin secara 
alamiah merupakan 'pelindung' dari selulosa dan hemiselulosa ${ }^{[16,17]}$. Proses pemisahan lignin, dengan bantuan bahan kimia, dan juga proses pemecahan molekul selulosa dapat berjalan efektif bila partikel biomasa kontak dengan bahan kimia yang digunakan. Oleh karena itu luas permukaan kontak, yang dipengaruhi oleh ukuran partikel, menentukan efektivitas proses. Penggilingan biomasa pada tahap persiapan bahan, diikuti dengan proses pengolahan awal (pretreatment) untuk pemisahan lignin, dan kemudian pemutusan polimer selulosa dan atau hemiselulosa (proses hidrolisa) menjadi tahaptahap penting yang akan mempengaruhi keberhasilan proses konversi ${ }^{[15,18,19]}$.

Indonesia memiliki berbagai jenis limbah biomasa lignoselulosa yang berpotensi untuk dimanfaatkan sebagai bahan baku pembuatan alkohol guna pencampur BBM. Potensi biomasa lignosellulosa dalam berbagai bentuk di Indonesia telah banyak dipublikasikan. Berbagai perguruan tinggi dan lembaga litbang telah meneliti proses pemanfaatan limbah ini menjadi bioetanol ${ }^{[6]}$ dan biobutanol ${ }^{[20-23]}$.

Penelaahan ini bertujuan untuk mendapatkan gambaran pengaruh dari ukuran partikel, sebagai salah satu variabel pada proses pemanfaatan biomasa untuk pembuatan alkohol, terutama pengaruhnya pada tingkat keberhasilan proses hidrolisa dan biaya proses keseluruhan. Hasil telaahan ini ditujukan untuk dijadikan pembanding pada pengolahan tandan kosong kelapa sawit (TKKS) menjadi bioetanol di Pusat Penelitian Kimia LIPI. Telaahan atas pengaruh ukuran partikel ini menjadi perhatian karena akan berpengaruh pada keekonomian proses pembuatan bioetanol dan biobutanol dimasa depan.

\section{METODE PENELITIAN}

Telaahan terkait pengaruh ukuran partikel biomasa pada beberapa aspek dalam proses pembuatan bioetanol dan biobutanol dari biomasa lignoselulosa dilakukan melalui penelaahan pustaka (desk study) secara eksploratif dan juga menggunakan data primer hasil penelitian sendiri di Pusat Penelitian Kimia LIPI. Dalam rangka mendapatkan penjelasan detail terkait proses, penulis berhubungan langsung dengan peneliti di Pusat Penelitian Kimia dan dengan penulis jurnal tertentu.

\section{HASIL DAN DISKUSI}

Secara skematis proses konversi biomasa lignoselulosa menjadi bioetanol atau biobutanol dilakukan melalui tahap persiapan bahan baku dimana bahan dikeringkan, dipotong dan digiling, kemudian dilanjutkan dengan pengolahan awal untuk memisahkan lignin, proses hidrolisa untuk mengkonversi selulosa dan atau hemiselulosa menjadi gula, dan fermentasi gula menjadi alkohol. Alkohol yang dihasilkan dimurnikan, melalui proses distilasi dan adsorpsi, sehingga mencapai kualitas untuk bahan bakar. Secara skematis proses digambarkan seperti pada gambar 1 .

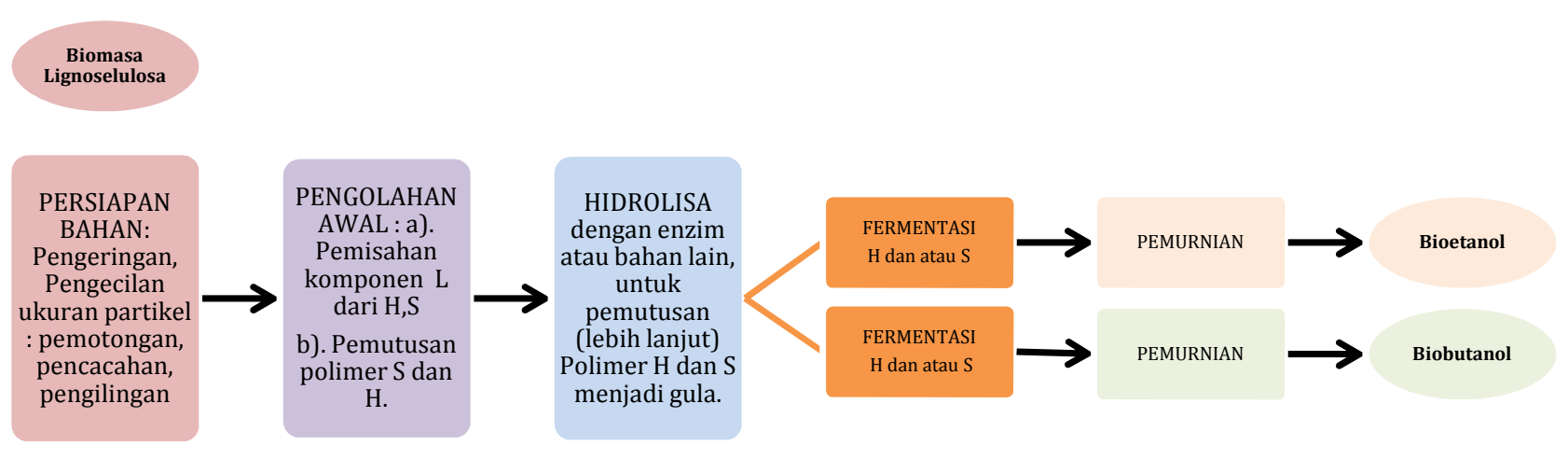


Gambar 1. Skema alur proses utama konversi biomasa lignoselulosa menjadi alkohol $\mathrm{H}$, hemiselulosa; S, Selulosa; L,lignin.(Dirangkum dari berbagai sumber ${ }^{[24-28]}$ ).

\subsection{Persiapan Bahan Baku: Pengaruh Proses Penggilingan pada Biomasa.}

Pada persiapan bahan baku dilakukan pengeringan, pencacahan dan penggilingan biomasa sehingga mencapai ukuran partikel yang diinginkan. Ukuran partikel biomasa lignoselulosa yang dipergunakan untuk membuat alkohol akan mempengaruhi dua sifat fisik yaitu i) berat jenis unggun (bulk density) biomasa yang kemudian akan mempengaruhi viskositas campuran biomasa dengan bahan kimia dalam unit pengolahan awal dan unit hidrolisa $^{[28]}$, serta ii) luas permukaan spesifik (specific surface area, SSA) yang akan menentukan luas permukaan kontak (accessible surface area, ASA) antara partikel biomasa dengan bahan kimia pada proses pengolahan awal, dan antara biomasa dengan enzim pada proses hidrolisa ${ }^{[28-31]}$. Luas permukaan spesifik (SSA) yaitu luas permukaan per satuan volum (atau berat) partikel biomasa ${ }^{[31]}$. Zhao dkk $(2012)^{[31]}$ mencatat bahwa penurunan ukuran partikel mikrokristal selulosa dari 25,52 $\mu \mathrm{m}$ menjadi $0,78 \mu \mathrm{m}$ menyebabkan SSA meningkat dari $0,24 \mathrm{~m}^{2} / \mathrm{gr}$ menjadi $25,50 \mathrm{~m}^{2} / \mathrm{gr}$.

Berbagai cara untuk memperkecil ukuran partikel biomasa lignoselulosa seperti pencacahan (chipping), penggilingan (grinding) dan penghalusan (milling) menggunakan ball mill, hammer mill atau lainnya menyebabkan penurunan kristalinitas selulosa dan meningkatkan digestabilitas dari lignoselulosa ${ }^{[28-30]}$, serta mempengaruhi porositas partikel ${ }^{[30]}$, yang semuanya akan mempengaruhi efektivitas reaksi hidrolisa dalam proses pembuatan bioetanol dan biobutanol.

Berdasarkan kajian kinetika, reaksi perubahan selulosa menjadi gula berjalan lebih cepat serta menghasilkan gula lebih banyak pada ukuran partikel biomasa yang lebih kecil dari pada partikel yang lebih besar ${ }^{[29]}$. Mereka menemukan bahwa pada partikel ukuran kecil (submikron) kecepatan produksi selobiosa meningkat 11,8 kali lipat dibandingkan partikel berukuran besar $(\mathrm{mm})^{[29]}$. Penelitian mereka ini memperlihatkan bahwa penghalusan partikel biomasa adalah cara penting untuk meningkatkan reaksi hidrolisa enzimatik.

Disamping mempengaruhi sifat fisik dan kimia, proses pengecilan ukuran partikel itu sendiri melalui pencacahan, penggilingan, dan penghalusan memerlukan energi besar. Disamping itu pengecilan ukuran partikel, yang akan meningkatkan viskositas campuran, menyebabkan energi yang diperlukan untuk proses pencampuran dalam unit pengolahan awal dan unit hidrolisa serta untuk pemompaan bahan akan lebih besar sehingga mempengaruhi jumlah keseluruhan kebutuhan energi dalam proses pembuatan alkohol ${ }^{[28-30]}$. Karena besarnya penggunaan energi, biaya pengilingan ini kurang lebih $1 / 3$ dari total biaya untuk persiapan (upgrading) bahan baku ${ }^{[32]}$. Oleh karena itu pemilihan cara penggilingan yang sesuai dalam proses pemanfaatan biomasa menjadi alkohol perlu diperhatikan. Tabel 2 memperlihatkan contoh kebutuhan energi untuk penggilingan biomasa.

Tabel 2. Energi yang dibutuhkan untuk Penggilingan Biomasa Lignoselulosa ${ }^{[28]}$

\begin{tabular}{|c|c|c|c|c|}
\hline \multirow{2}{*}{ No } & \multirow{2}{*}{ Bahan Lignoselulosa } & \multirow{2}{*}{$\begin{array}{c}\text { Ukuran partikel } \\
(\mathrm{mm})\end{array}$} & \multicolumn{2}{|c|}{ Konsumsi Energi (kWh/ton) } \\
\hline & & & Knife Mill & Hammer Mill \\
\hline \multirow[t]{4}{*}{1} & Kayu keras (Hardwood) & 1.60 & 130 & 130 \\
\hline & & 2.54 & 80 & 120 \\
\hline & & 3.2 & 50 & 115 \\
\hline & & 6.35 & 25 & 95 \\
\hline \multirow[t]{2}{*}{2} & Jerami gandum (Straw) & 1.60 & 7.5 & 42 \\
\hline & & 2.54 & 6.4 & 29 \\
\hline \multirow[t]{2}{*}{3} & Limbah tanaman jagung (Corn stover) & 1.60 & NA & 14 \\
\hline & & 3.20 & 20 & 9.6 \\
\hline
\end{tabular}


Pengecilan ukuran partikel biomasa adalah proses tahap pertama yang banyak pengaruhnya dalam konversi biomasa menjadi bahan bakar, karena akan meningkatkan luas permukaan subtrat, meningkatkan proses perpindahan masa dan perpindahan panas, serta meningkatkan asesabilitas enzim ke permukaan biomasa, yang pada akhirnya akan meningkatkan efisiensi proses pengolahan awal dan hidrolisa enzimatik ${ }^{[33,34]}$.

\subsection{Pengaruh Ukuran Partikel Pada Pengolahan Awal}

Pengolahan awal biomasa, yang ditujukan untuk memisahkan lignin dari selulosa dan hemiselulosa, dapat dilakukan melalui proses tanpa bahan kimia seperti dengan ekstrusi mekanis panas (thermo mechanical extrusion $)^{[35]}$ atau penggunaan bahan kimia atau proses campuran ${ }^{[6]}$. Selain terjadi pemisahan lignin, pada tahap pengolahan awal ini sebagian selulosa dan hemiselulosa juga terhidrolisa, dan hidrolisa lebih lanjut terjadi pada proses hidrolisa $^{[25]}$. Pengolahan awal ini dilakukan sebelum hidrolisa dengan tujuan agar selulosa dan atau hemiselulosa lebih mudah dihidrolisa karena lignin sudah berkurang atau tidak ada lagi.

Selulosa, merupakan homopolimer terdiri dari rangkaian unit glukosa yang tersambung melalui ikatan glikosida, sedangkan hemiselulosa merupakan heteropolimer yang disusun oleh pentosa (silosa dan arabinosa) dan heksosa (manosa, galaktosa dan glukosa) ${ }^{[36,37]}$. Berbagai bentuk gula tersebut merupakan bahan utama yang digunakan untuk menghasilkan bioetanol ataupun biobutanol. Lignin merupakan polimer aromatik yang komplek dengan variasi strukturnya tergantung pada tumbuhan asal, relatif sulit dihancurkan oleh $\operatorname{mikroba}^{[17]}$.

$\begin{array}{ccc}6.35 & 15 & \text { NA } \\ 9.5 & 3.2 & \text { NA }\end{array}$

E. Khullar, 2012 $2^{[38]}$ meneliti pengaruh ukuran partikel, melalui 3 macam ukuran yaitu 0,08, 2 dan $6 \mathrm{~mm}$ ukuran ayakan, dalam proses pembuatan bioetanol dari rumput gajah (Miscanthus) dengan berbagai macam proses pengolahan awal yaitu menggunakan air panas, asam encer, serta ammonium hidrosida encer. Dia mendapatkan bahwa ukuran partikel yang lebih kecil $(0,08 \mathrm{~mm})$ menghasilkan peningkatan konversi polisakarida menjadi monosakarida pada semua proses pengolahan awal. Peningkatan konversi polisakarida ini juga terjadi pada rumput gajah yang digiling, dibandingkan dengan rumput gajah tidak digiling, meskipun biomasa tersebut tidak mengalami pengolahan awal. Hasil hidrolisa dengan enzim meningkat antara $40-70 \%$ pada bahan yang mengalami perlakuan awal, tetapi hanya meningkat $10-20 \%$ pada bahan yang tidak mengalami perlakuan awal.

Karena biomasa lignoselulosa adalah bahan yang tidak larut dalam air, maka dalam proses konversi biomasa menjadi alkohol, akan terlibat reaksi kimia heterogen yang memerlukan kontak/pertemuan antara biomasa dengan bahan kimia, baik pada tahap pengolahan awal yang menggunakan bahan kimia maupun antara selulosa dan atau hemiselulosa dengan enzim atau bahan lain yang dipakai dalam proses hidrolisa ${ }^{[39]}$. Oleh karena itu, proses pengolahan awal dengan menggunakan bahan kimia memerlukan sistem pencampuran yang baik sehingga setiap permukaan partikel biomasa dapat kontak dengan bahan kimia yang digunakan, pada waktu yang diperlukan, untuk memisahkan lignin dari selulosa dan hemiselulosa.

Keberhasilan proses pengolahan awal, dalam arti seberapa jauh komponen lignin dapat dipisahkan, akan menentukan tingkat keberhasilan proses hidrolisa karena konversi selulosa menjadi glukosa sudah tidak dihambat oleh lignin. Karena banyaknya parameter yang menentukan tingkat keberhasilan proses pengolahan awal seperti ukuran partikel, kondisi operasi, serta jumlah bahan kimia, maka pengolahan awal dipandang sebagai salah satu tahap yang paling mahal dan menentukan dalam 
konversi biomasa menjadi gula yang dapat di fermentasi ${ }^{[18]}$.

\subsection{Pengaruh Ukuran Partikel Pada Hidrolisa}

Pemutusan rangkaian polimer selulosa dan hemiselulosa pada hidrolisa bisa melalui proses enzimatik atau $\mathrm{kimia}^{[31]}$. Pemecahan selulosa dan atau hemiselulosa yang melalui proses hidrolisa enzimatik umumnya dilakukan dengan bantuan enzim seperti celullase, xylanase $^{[26,40]}$. Proses hidrolisa enzimatik ini ditujukan untuk menyempurnakan pemutusan rantai polimer selulosa dan atau hemiselulosa, yang sebagian pemutusan telah terjadi pada proses pengolahan awal, menjadi monosakarida/senyawa gula dan kemudian diikuti dengan proses fermentasi senyawa gula menjadi alkohol yang diinginkan. Jumlah selulosa maupun hemiselulosa yang dapat diubah menjadi gula akan sangat menentukan keekonomian proses pembuatan alkohol ${ }^{[18,30]}$.

Prasyarat penting dalam hidrolisa biomasa lignoselulosa oleh enzim atau bahan kimia lain adalah penyerapan (adsorpsi) enzim ke permukaan substrat sehingga terjadi kontak antara substrat dan enzim. Oleh karena itu luas permukaan yang dapat kontak, ASA, menjadi faktor penentu penting dalam proses pemutusan rantai selulosa oleh enzim atau bahan lainnya, sehingga menghasilkan gula yang dapat difermentasi menjadi alkohol. ASA dipengaruhi oleh porositas, volume pori, dan ukuran partikel biomasa ${ }^{[31]}$. A.P. Sinitsyn, dkk $(1991)^{[41]}$ mendapatkan untuk material seperti selulosa murni, $\alpha$-selulosa, mikrokristal selulosa dan serat katun, peningkatan SSA dan rendahnya indek kristalinitas mempercepat proses hidrolisa enzimatik. Tetapi, pada bagase tebu hanya perubahan SSA yang mempengaruhi reaktivitas proses hidrolisa.

E.K. Bahrin, dkk $(2012)^{[42]}$ mencatat bahwa setelah pengolahan awal dengan uap lewat panas (superheated steam) dan $12 \mathrm{jam}$ proses sakarifikasi, partikel TKKS yang berukuran kecil $(0,25 \mathrm{~mm})$ menghasilkan glukosa lebih banyak dari pada partikel TKKS besar $(0,425 \mathrm{~mm})$. Disamping itu mereka menyatakan bahwa bila dalam hasil gilingan biomasa jumlah partikel berukuran kecil lebih banyak dari pada jumlah partikel berukuran besar maka proses hidrolisa enzimatik akan meningkat. Kecendrungan yang sama juga didapatkan pada hidrolisa serbuk gergaji, dimana reaksi enzimatik pada ukuran partikel yang lebih kecil lebih cepat dibandingkan partikel yang lebih besar ${ }^{[31]}$.

I.Torrado, dkk (2014) $)^{[43]}$ yang menghidrolisa Giant Reed (Arundo donax L) menggunakan asam sulfat encer dengan lima macam ukuran partikel dari $0,25 \mathrm{~mm}$ sampai 4 $\mathrm{mm}$ menyimpulkan bahwa semakin kecil ukuran partikel semakin meningkatkan glukosa hasil hidrolisa selulosa, tetapi tidak ada pengaruhnya pada gula hasil hidrolisa hemiselulosa. Torrado dkk menjelaskan bahwa hasil hidrolisa Giant Reed didominasi oleh silosa, sedangkan glukosa lebih sedikit. Penurunan ukuran partikel dari < 1,6 mm ke < $0.25 \mathrm{~mm}$ menyebabkan kenaikan glukosa dari $2.08 \mathrm{~g} / \mathrm{L}$ ke $2,30 \mathrm{~g} / \mathrm{L}$, sedangkan perubahan silosa tidak signifikan yaitu dari $28.14 \mathrm{~g} / \mathrm{L}$ ke $28.71 \mathrm{~g} / \mathrm{L}$. Mereka ${ }^{(43)}$ juga mengemukakan bahwa hasil yang sama ditemukan juga oleh peneliti lain untuk bahan baku jerami padi. Pada jerami padi, bila ukuran partikel diperkecil dari ukuran antara 2 sampai $55 \mathrm{~mm}$ menjadi 0,295 sampai $0,833 \mathrm{~mm}$, maka terjadi kenaikan glukosa hasil hidrolisa sekitar $44 \%$, sedangkan gula turunan dari hemiselulosa hampir tidak dipengaruhi. Disimpulkan bahwa memperkecil ukuran partikel dapat meningkatkan gula dari hidrolisa selulosa, tetapi tetapi tidak mempengaruhi gula dari hemiselulosa.

Proses hidrolisa enzimatik merupakan suatu faktor pembatas (a limiting factor) dalam rangkaian proses konversi biomasa lignoselulosa menjadi bahan kimia maupun bahan bakar. Pembatasan ini disebabkan karena berbagai sifat alamiah seperti kandungan asetil dan lignin, kristalinitas selulosa, serta sifat lain seperti ukuran partikel, luas permukaan dan volum pori partikel biomasa yang mempengaruhi sejauh mana hidrolisa bisa dilakukan $^{[44]}$.

Kajian ini memperlihatkan bahwa pembuatan bioetanol dan biobutanol dari 
biomasa lignoselulosa mengikuti alur proses yang sama seperti dalam Gambar 1, perbedaan penting adalah pada bahan pendukung proses fermentasi yaitu variasi jenis mikroba yang digunakan, yaitu ragi atau bahteri. Proses fermentasi untuk memproduksi bioetanol banyak dilakukan dengan bantuan ragi kelompok Saccaharomyces, misal $S$. cerevisiae $^{[45]}$, dan untuk pembuatan biobutanol yang banyak diteliti adalah mikroba spesies Clostridium $^{[46]}$. Capaian proses pembuatan bioetanol secara keseluruhan sangat tergantung pada keberhasilan proses pengolahan awal dan hidrolisa, yang keduanya dipengaruhi oleh berbagai faktor antara lain komposisi kimia biomasa dan sifat fisik bahan antara lain ukuran partikel $^{[28]}$. Pengaruh ukuran partikel pada pembuatan biobutanol juga ditemukan oleh para peneliti lain ${ }^{[47,48]}$. Jonglertjunya ${ }^{[47]}$ dalam proses pembuatan biobutanol dari bagase tebu memperlihatkan bahwa terjadi kenaikan kandungan jumlah gula pereduksi dari partikel bagase berukuran kecil $(0,212-1,18 \mathrm{~mm})$ dibandingkan dengan yang diperoleh dari partikel yang lebih besar, tidak diayak (ungraded) dan berukuran diatas $1,18 \mathrm{~mm}$, yaitu dari $17,7 \mathrm{~g} / \mathrm{L}$ ke $24,2 \mathrm{~g} / \mathrm{L}$. Akan tetapi gula pereduksi hasil hidrolisa dari partikel yang lebih kecil lagi $(0,053-0,063 \mathrm{~mm})$ tidak memperlihatkan perbedaan yang nyata dengan hasil dari partikel 0,212 - 1,18 mm, yaitu sebesar 24,0 g/L. Mereka menyimpulkan ukuran partikel yang optimal untuk hidrolisa bagase tebu pada pembuatan biobutanol pada daerah sekitar 0,212-1,18 mm.

Dari beberapa hasil penelitian diatas jelas terlihat bahwa memperkecil ukuran partikel biomasa akan cendrung memperbesar SSA dan ASA, akan meningkatkan digestabilitas selulosa sehingga mendorong peningkatan proses hidrolisa selulosa. Tetapi pengecilan ukuran partikel biomasa tidak ada pengaruhnya pada hidrolisa hemiselulosa. Pengaruh ukuran partikel ini pada hidrolisa selulosa masih menjadi kontroversi karena beberapa penelitian lain menunjukkan hasil yang berbeda ${ }^{[30,49]}$.

\subsection{Pengaruh Ukuran Partikel Pada Dalam Pembuatan Enzim}

Enzim berperan penting dalam proses hidrolisa, oleh karena itu beberapa peneliti mencoba menelaah pengaruh ukuran partikel pada pembuatan enzim. E.K.Bahrin, dkk $(2011)^{[50]}$ menjelaskan bahwa ukuran partikel bahan baku mempengaruhi proses fermentasi padat untuk menghasilkan beberapa enzim selulase (exoglucanase, endoglucanase and $\beta$ glucosidase) dari bahan baku TKKS. Enzim dibuat dengan menggunakan 4 variasi ukuran diameter partikel yaitu $0,25-0,3 \mathrm{~mm}, 0,42-$ $0,6 \mathrm{~mm}, 0,84-1,0 \mathrm{~mm}$ dan $5-10 \mathrm{~mm}$. Produksi enzim exoglucanase dan $\beta$ glucosidase terbanyak diperoleh dari ukuran partikel 0,42 - 0,6 mm, sedangkan untuk produksi endoglucanase terbanyak diperoleh dari ukuran partikel 0,84 - 1,0 mm. Mereka menjelaskan semakin kecil partikel, sampai batas optimum, akan menyebabkan permukaan semakin luas dan porositas semakin kecil, semakin banyak terjadi kemungkinan kontak antara bahan, sehingga semakin mudah terjadi reaksi. Mereka juga mencatat bahwa ada hubungan terbalik antara porositas dan luas permukaan substrat. Penelitian mereka ${ }^{[50]}$ menunjukkan bahwa ukuran substrat $0,4 \mathrm{~mm}$ merupakan ukuran optimum untuk fermentasi produksi selulase. Penelitian lain ${ }^{[51]}$, yang menggunakan mikroba berbeda yaitu strain Pleurotus ostreatus dengan bahan baku bagasse tebu, memperlihatkan bahwa pengaruh ukuran substrat dalam produksi enzim selulase juga memiliki kecendrungan yang sama dengan hasil E.K.Bahrin ${ }^{[50]}$.

Telaahan ini menunjukkan bahwa ukuran partikel biomasa juga mempengaruhi proses pembuatan enzim dan hasilnya. Pada proses pembuatan enzim dengan bahan baku biomasa lignoselulosa terdapat ukuran partikel tertentu yang memberikan hasil yang optimal. Untuk bahan baku TKKS dan bagase tebu ukuran partikel yang optimal sekitar $0,4-1 \mathrm{~mm}$.

\subsection{Ukuran Partikel Biomassa Tidak Berpengaruh pada Hidrolisa}

Disamping banyak penelitian yang memperlihatkan bahwa semakin kecil ukuran partikel, sampai batas tertentu, akan semakin baik bagi proses hidrolisa, tetapi beberapa 
penelitian lain memperlihatkan bahwa pengecilan ukuran partikel tidak signifikan pengaruhnya pada konversi biomasa menjadi alkohol.

A.L.L.Cesario, dkk $(2014)^{[49]}$ yang meneliti pembuatan etanol dari bagase tebu dengan ukuran partikel 2, 1 dan $0,5 \mathrm{~mm}$ (berdasarkan ukuran lubang ayakan) menyatakan bahwa ukuran partikel tidak signifikan pengaruhnya pada hasil proses pengolahan awal yang menggunakan asam sulfat encer. Tetapi mereka memperoleh lebih banyak jumlah hemiselulosa yang dapat dilarutkan pada partikel yang lebih halus dari pada bagase tebu yang tidak dihaluskan. Mereka menyimpulkan bahwa pada proses pembuatan bioetanol dari bagase tebu, melalui pengolahan awal dengan asam encer dan diikuti dengan hidrolisa enzimatik, variasi ukuran partikel bagase 2,0 1,0 dan $0,5 \mathrm{~mm}$ tidak memperlihatkan pengaruh secara signifikan pada proses hidrolisa.

N.Khienpanya,dkk $(2015)^{[52]}$ meneliti pembuatan bioetanol dari batang kelapa sawit mempergunakan 4 macam ukuran partikel yaitu $0,425-1,5 \mathrm{~mm}, 0,250-0,425 \mathrm{~mm}$, dibawah $0,25 \mathrm{~mm}$, dan partikel yang dihaluskan tetapi tidak diayak. Hasil penelitian mereka memperlihatkan bahwa memperkecil ukuran partikel biomasa tidak memberikan perbedaan yang signifikan pada produktivitas proses dan jumlah etanol yang dihasilkan. Mereka menemukan biomasa dengan partikel $(0,425-$ $1,5 \mathrm{~mm})$ menghasilkan bioetanol yang lebih banyak dari pada ukuran partikel yang lebih kecil (dibawah 0,25 mm), meskipun perbedaannya tidak signifikan secara statistik. Mereka berspekulasi meskipun pengecilan ukuran partikel meningkatkan SSA tetapi volum pori belum tentu meningkat, bahkan bisa turun. Hal ini terjadi karena rusaknya pori dalam proses penggilingan biomasa. Pendapat ini sejalan dengan hasil peneliti lain yang meneliti pengaruh distribusi ukuran pori kayu keras dan lunak dalam proses hidrolisa dengan enzim ${ }^{[53]}$. Mereka menyatakan bahwa ukuran pori subtrat, dalam hubungannya dengan ukuran dari enzim, merupakan faktor pembatas utama dalam reaksi hidrolisa enzimatik.
Dari beberapa penelitian ini dipahami bahwa pengecilan ukuran partikel akan membantu proses pengolahan awal, pemisahan lignin dari selulosa dan hemiselulosa, tetapi pengecilan ukuran partikel yang menyebabkan rusaknya pori subtrat tidak mempengaruhi proses hidrolisa selulosa menjadi gula.

\subsection{Pengaruh Ukuran Partikel Pada Biaya Proses}

Seperti dinyatakan diatas, proses pencacahan, penggilingan, penghalusan, akan menghasilkan partikel kecil yang mempunyai permukaan yang luas, akan tetapi proses penghalusan partikel ini memerlukan energi yang besar, yang akan mempengaruhi biaya dan tingkat keekonomian proses pembuatan bioetanol atau biobutanol dari biomasa lignoselulosa.

S.H.Dugue, dkk (2015) ${ }^{[54]}$ yang mengkaji pembuatan bioetanol dari 10 macam biomasa memperlihatkan bahwa biaya produksi pada tahun 2014 sekitar 0,65 dollar per liter etanol dimana biaya utilitas, berupa biaya energi dan air, sebesar 45,3\% dari total biaya varibel. J.A. Quentero,dkk (2013) ${ }^{[55]}$ melalui proses simulasi untuk 4 macam biomasa lignoselulosa yaitu bagase tebu, sekam padi, TKKS, dan tangkai buah kopi memperlihatkan bahwa biaya utilitas, terutama energi, berkisar antara $37-48,9 \%$ dari total biaya produksi bioetanol. Dari tabel 2 terlihat bahwa pengecilan ukuran partikel meningkatkan biaya energi. Sebagai contoh, pengecilan ukuran partikel kayu dengan knife mill dari 2,54 ke $1,60 \mathrm{~mm}$ meningkatkan penggunaan energi dari $80 \mathrm{ke} 130 \mathrm{kWh} / \mathrm{ton}$, atau sebesar $62,5 \%$, sedangkan dengan hammer mill meningkatkan penggunaan energi dari 120 ke $130 \mathrm{kWh} /$ ton atau sebesar 8,3\%.-

B.C.Vidal, dkk (2011) ${ }^{[56]}$ menyampaikan bahwa ukuran partikel biomasa mempengaruhi tingkat ekonomis proses pemanfaatan lignoselulosa karena ukuran partikel mempengaruhi biaya operasi dan capaian konversi. Mereka menyatakan bahwa pengolahan fisik, antara lain pengecilan ukuran partikel sampai ukuran maksimum bisa 
mempengaruhi capaian konversi sampai dengan $50 \%$, sedangkan pengaruh proses kimia bisa diatas $70 \%$. Ukuran partikel maksimum didefinisikan sebagai ukuran terbesar dimana dibawah ukuran tersebut tidak ada pengaruh ukuran partikel pada proses konversi biomasa menjadi etanol ${ }^{[56]}$. Ukuran partikel maksimum ini tergantung pada jenis biomasa, dan bahan pembantu yang dipakai pada pengolahan awal seperti air panas, uap air, asam, basa, atau bahan lainnya. Oleh karena itu Vidal $\mathrm{dkk}^{[56]}$ menyarankan kajian ukuran partikel biomasa ini perlu dilakukan pada konversi biomasa menjadi sumber energi terbarukan.

Kajian ini memperlihatkan bahwa proses penghalusan ukuran partikel bahan baku akan mempengaruhi biaya pembuatan alkohol dari biomasa lignoselulosa melalui dua cara. Pertama, mempengaruhi kebutuhan daya yang diperlukan untuk persiapan bahan. Ukuran partikel yang dituju akan mempengaruhi jumlah energi untuk proses persiapan bahan, semakin halus partikel yang diinginkan akan semakin besar energi diperlukan. Disamping itu, partikel yang semakin halus menyebabkan perubahan densitas dan viskositas sehingga kebutuhan energi pada unit-unit pencampuran akan semakin besar. Biaya energi merupakan biaya yang dominan dari total biaya produksi, yaitu bisa sampai dengan 48,9 \% dari biaya produksi ${ }^{[55]}$. Kedua, ukuran partikel juga mempengaruhi tingkat keberhasilan proses pengolahan awal dan hidrolisa serta berpotensi meningkatkan hasil alkohol. Semuanya ini pada akhirnya akan mempengaruhi biaya produksi (cost of production) bioetanol atau biobutanol dari biomasa lignoselulosa. Oleh karena itu, meskipun pengecilan ukuran partikel berpeluang untuk meningkatkan produksi alkohol per satuan berat bahan baku, tetapi juga menyebabkan kenaikan biaya produksi, sehingga perhitungan yang tepat perlu dilakukan bila akan memperkecil ukuran partikel bahan baku.

\subsection{Pengaruh Ukuran Partikel Pada Biaya Proses}

Seperti dinyatakan diatas, proses pencacahan, penggilingan, penghalusan, akan menghasilkan partikel kecil yang mempunyai permukaan yang luas, akan tetapi proses penghalusan partikel ini memerlukan energi yang besar, yang akan mempengaruhi biaya dan tingkat keekonomian proses pembuatan bioetanol atau biobutanol dari biomasa lignoselulosa.

S.H.Dugue, dkk (2015) ${ }^{[54]}$ yang mengkaji pembuatan bioetanol dari 10 macam biomasa memperlihatkan bahwa biaya produksi pada tahun 2014 sekitar 0,65 dollar per liter etanol dimana biaya utilitas, berupa biaya energi dan air, sebesar 45,3\% dari total biaya varibel. J.A. Quentero,dkk (2013) ${ }^{[55]}$ melalui proses simulasi untuk 4 macam biomasa lignoselulosa yaitu bagase tebu, sekam padi, TKKS, dan tangkai buah kopi memperlihatkan bahwa biaya utilitas, terutama energi, berkisar antara $37-48,9 \%$ dari total biaya produksi bioetanol. Dari tabel 2 terlihat bahwa pengecilan ukuran partikel meningkatkan biaya energi. Sebagai contoh, pengecilan ukuran partikel kayu dengan knife mill dari 2,54 ke 1,60 mm meningkatkan penggunaan energi dari $80 \mathrm{ke} 130 \mathrm{kWh} / \mathrm{ton}$, atau sebesar 62,5\%, sedangkan dengan hammer mill meningkatkan penggunaan energi dari 120 ke $130 \mathrm{kWh} /$ ton atau sebesar 8,3\%.-

B.C.Vidal, dkk (2011) ${ }^{[56]}$ menyampaikan bahwa ukuran partikel biomasa mempengaruhi tingkat ekonomis proses pemanfaatan lignoselulosa karena ukuran partikel mempengaruhi biaya operasi dan capaian konversi. Mereka menyatakan bahwa pengolahan fisik, antara lain pengecilan ukuran partikel sampai ukuran maksimum bisa mempengaruhi capaian konversi sampai dengan $50 \%$, sedangkan pengaruh proses kimia bisa diatas $70 \%$. Ukuran partikel maksimum didefinisikan sebagai ukuran terbesar dimana dibawah ukuran tersebut tidak ada pengaruh ukuran partikel pada proses konversi biomasa menjadi etanol ${ }^{[56]}$. Ukuran partikel maksimum ini tergantung pada jenis biomasa, dan bahan pembantu yang dipakai pada pengolahan awal seperti air panas, uap air, asam, basa, atau bahan lainnya. Oleh karena itu Vidal $\mathrm{dkk}^{[56]}$ menyarankan kajian ukuran partikel biomasa ini perlu dilakukan pada konversi biomasa menjadi sumber energi terbarukan. 
Kajian ini memperlihatkan bahwa proses penghalusan ukuran partikel bahan baku akan mempengaruhi biaya pembuatan alkohol dari biomasa lignoselulosa melalui dua cara. Pertama, mempengaruhi kebutuhan daya yang diperlukan untuk persiapan bahan. Ukuran partikel yang dituju akan mempengaruhi jumlah energi untuk proses persiapan bahan, semakin halus partikel yang diinginkan akan semakin besar energi diperlukan. Disamping itu, partikel yang semakin halus menyebabkan perubahan densitas dan viskositas sehingga kebutuhan energi pada unit-unit pencampuran akan semakin besar. Biaya energi merupakan biaya yang dominan dari total biaya produksi, yaitu bisa sampai dengan 48,9 \% dari biaya produksi $^{[55]}$. Kedua, ukuran partikel juga mempengaruhi tingkat keberhasilan proses pengolahan awal dan hidrolisa serta berpotensi meningkatkan hasil alkohol. Semuanya ini pada akhirnya akan mempengaruhi biaya produksi (cost of production) bioetanol atau biobutanol dari biomasa lignoselulosa. Oleh karena itu, meskipun pengecilan ukuran partikel berpeluang untuk meningkatkan produksi alkohol per satuan berat bahan baku, tetapi juga menyebabkan kenaikan biaya produksi, sehingga perhitungan yang tepat perlu dilakukan bila akan memperkecil ukuran partikel bahan baku.

\subsection{Penelitian Pengaruh Ukuran Partikel Pada Pembuatan Bioetanol di Indonesia}

Penelitian dari dalam negeri terkait pengaruh ukuran partikel terhadap proses konversi biomasa menjadi alkohol belum banyak ditemukan. Pada pembuatan bioetanol dari sorgum (bukan lignoselulosa) dengan ukuran partikel antara $0,17-0,25,0,25-0,40$ dan 0,40 - 0,84 mm ditemukan bahwa semakin halus partikel bahan baku hasil bioetanol semakin banyak ${ }^{[57]}$. D.S.Kamara,dkk $(2007)^{[58]}$ yang memanfaatkan batang pisang sebagai bahan baku pembuatan glukosa melalui proses hidrolisa enzimatik memperlihatkan bahwa pengecilan ukuran partikel batang pisang dari $0,84, \quad 0,25, \quad 0,18, \quad$ sampai $0,15 \mathrm{~mm}$ mempengaruhi jumlah gula pereduksi yang dihasilkan. Peningkatan hasil hidrolisa dari partikel terbesar sampai terkecil mencapai kurang lebih 2 kali lipat.

Pusat Penelitian Kimia (PPKimia) LIPI meneliti pemanfaatan TKKS untuk bahan baku pembuatan bioetanol pada skala pilot dengan kapasitas $10 \mathrm{~L}$ per hari etanol kualitas untuk bahan bakar (99,6 \%). Pembuatan bioetanol ini dilakukan melalui lima tahap proses utama yaitu persiapan bahan baku, pengolahan awal (pretreatment), hidrolisa, fermentasi dan pemurnian produk bioetanol ${ }^{[24]}$. Pada penelitian ini TKKS yang telah dikeringkan digiling dengan hammer mill dengan ukuran saringan 3 $\mathrm{mm}$, dan hasil gilingan tidak diayak lagi. TKKS kering hasil gilingan ini dicampur dengan $\mathrm{NaOH}$ encer untuk pemisahan $\operatorname{lignin}^{[24]}$. Proses pembuatan bioetanol di PP Kimia LIPI menghasilkan $0,178 \mathrm{~L}$ etanol $/ \mathrm{kg}$ TKKS kering, dengan efisiensi proses hidrolisa adalah 93,8 $\%{ }^{[59]}$. Hasil analisis atas ukuran partikel TKKS produk dari gilingan hammer mill diperlihatkan pada tabel 3.

Tabel 3. Distribusi Ukuran Partikel TKKS yang dipakai PP Kimia LIPI (\% berat kering)

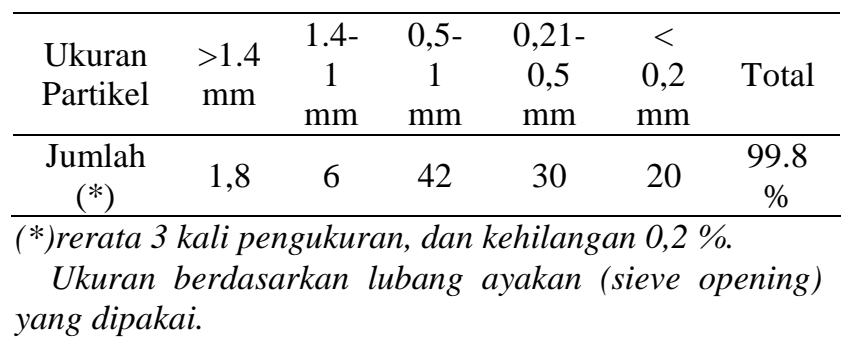

Tabel 3 memperlihatkan bahwa sekitar $92 \%$ (berat) TKKS yang digunakan PP KimiaLIPI berukuran dibawah $1 \mathrm{~mm}$, dan $7,8 \%$ diatas $1 \mathrm{~mm}$. Pengamatan secara visual memperlihatkan bahwa partikel TKKS kering hasil ayakan yang berukuran diatas $1 \mathrm{~mm}$ lebih banyak berbentuk silinder, dan ukuran (> 1 $\mathrm{mm})$ kelihatan lebih mencerminkan ukuran panjang, bukan ukuran diameter atau lebar serat. Sebagian besar partikel TKKS hasil ayakan yang berukuran dibawah $1 \mathrm{~mm}$ berbentuk mendekati pipih persegi dan sebagian tak beraturan, sangat sedikit yang berbentuk silinder. H.Lu, dkk (2010) $)^{[60]}$ menyatakan bahwa luas permukaan untuk partikel berbentuk 
silinder jauh lebih besar dari pada partikel berbentuk bola atau kotak.

Dari kajian ini diperkirakan hal berikut terkait penelitian pemanfaatan TKKS untuk bahan baku bioetanol. Pertama, diperkirakan ukuran maksimum partikel untuk konversi TKKS menjadi alkohol adalah antara 0,4 sampai $1 \mathrm{~mm}$. Penggunaan partikel TKKS dibawah ukuran $0,4 \mathrm{~mm}$ diperkirakan tidak akan terlihat lagi pengaruhnya pada proses hidrolisa dan proses konversi secara keseluruhan. Kedua, diperkirakan efisiensi hidrolisa 93,8\% sudah optimal. TKKS hasil penggilingan lebih banyak yang berbentuk kotak pipih atau bulat dimana $92 \%$ bahan berukuran dibawah ukuran partikel maksimal ( $<1 \mathrm{~mm})$. Penggilingan lebih lanjut dan pengayakan, sehingga menghasilkan ukuran partikel yang lebih halus dan lebih seragam, diperkirakan tidak akan banyak pengaruhnya pada hidrolisa dan jumlah bioetanol yang akan dihasilkan, karena pemisahan partikel dengan pengayakan tidak akan banyak mengubah luas permukaan spesifik dari partikel TKKS yang digunakan. Penggilingan lebih lanjut dan pengayakan hanya akan menambahkan biaya proses. Meskipun demikian penelitian untuk melihat pengaruh ukuran partikel TKKS ini perlu dilakukan dimasa depan untuk mengkonfirmasi efisiensi proses pengolahan awal dan hidrolisa yang telah dicapai.

\section{KESIMPULAN DAN SARAN}

\subsection{Kesimpulan}

Telaahan ini memperlihatkan bahwa proses penggilingan dan perubahan ukuran partikel biomasa sebagai bahan baku pembuatan bioetanol atau biobutanol mempengaruhi sifat fisik bahan baku. Proses penggilingan, dalam upaya memperkecil ukuran partikel, mempengaruhi dua hal yaitu terjadi penurunan kristalinitas selulosa dan perubahan porisitas. Kedua perubahan ini akan mempengaruhi efektivitas proses hidrolisa dan akhirnya mempengaruhi capaian proses pembuatan alkohol secara keselururuhan. Perubahan ukuran partikel biomasa mempengaruhi densitas unggun bahan dan viskositas dari campuran dalam unit proses sehingga mempengaruhi kebutuhan energi, dan pada akhirnya mempengaruhi biaya proses.

Di dalam literatur terpublikasi terdapat perbedaan hasil penelitian terkait pengaruh ukuran partikel pada proses hidrolisa selulosa menjadi gula. Lebih banyak penelitian yang memperlihatkan bahwa semakin kecil ukuran partikel, sampai batas ukuran partikel maksimum, semakin banyak jumlah selulosa yang dapat dikonversi menjadi gula, dan semakin positif pengaruhnya pada capaian keseluruhan proses.

\subsection{Saran}

Indonesia memiliki berbagai jenis biomasa lignoselulosa yang potensial untuk dijadikan bahan baku bioetanol atau biobutanol antara lain tandan kosong kelapa sawit dan bagase tebu. Mengingat perbedaan kandungan lignin, selulosa dan hemiselulosa, serta perbedaan sifat dari berbagai biomasa lignoselulosa, maka dalam pemanfaatan biomasa menjadi bahan baku pembuatan alkohol, pengaruh ukuran partikel layak untuk menjadi perhatian para peneliti. Dalam penelitian dan pengembangan pembuatan alkohol dari bahan baku tandan kosong kelapa sawit atau bagase tebu sebaiknya digunakan ukuran partikel antara $0,4-1 \mathrm{~mm}$.

\section{UCAPAN TERIMA KASIH}

Penulis mengucapkan terima kasih pada Bpk Tupan dari PDII yang memfasilitasi dan membantu pencarian berbagai dokumen pendukung, Terima kasih disampaikan juga pada tim penelitian bioetanol di PP Kimia lainnya yang telah menjelaskan hasil penelitian di PP Kimia, dan pada Bpk Amsir yang telah membantu dalam melakukan analisis ukuran partikel TKKS.

\section{DAFTAR PUSTAKA}

[1] M.A.Carriquiry, X.Du, dan G.R.Timilsina. Second generation 
biofuels: Economics and policies, Energy Policy, 39: 4222-4234 (2011).

[2] A. Eisentraut (Ed). Sustainable production of second-generation biofuels : Potential and perspectives in major economies and developing countries, International Energy Agency (OECD/IEA), Information Paper, February, 2010, hal 7.

[3] B. Stefan. Towards Sustainable Production and Use of Resources: Assessing Biofuels, United Nation Environmental Program (UNEP) Report, 2009, Section 3.

[4] M. Balat dan H.Balat. Recent trends in global production and utilization of bioethanol fuel. Applied Energy, 86 : 22732282 (2009)

[5] P. Kaparaju, M. Serrano, A. B. Thomsen, P. Kongjan, dan I. Angelidaki. Bioethanol, biohydrogen and biogas production from wheat straw in a biorefinery concept. J. Bioresource Technology, 100: 2562-2568 (2009).

[6] S. Aiman. Perkembangan teknologi dan tantangan dalam riset bioetanol di Indonesia, J Kimia Terapan Indonesia, 16 (2) : 108-117 (2014).

[7] B.E. Dale. A New industry has been launched : The cellulosic biofuels ship (finally) sails, Biofules, Bioprod. Bioref, 9: 1-3 (2015).

[8] J.Lane. Who's building what, where, now. 29 projects in construction or in commissioning in Africa, Europe, Asia, the Middle East, Australia and the Americas, Biofuel Digest, Nov 17, 2015.

[9] V.Hönig, M. Kotek dan J. Mařík. Use of butanol as a fuel for internal combustion engines, Agronomy Research 12(2) : 333340 (2014).

[10] N.R.Baral, J. Li dan A.K. Jha. Perspective and prospective of pretreatment of corn straw for butanol production. Appl. Biochem Biotechnol 172:840-853 (2014).
[11] Anonim, The biofuel of the future, http://www.butamax.com/the-BiobutanolAdvantage.aspx. (diunduh 4 November 2015).

[12] Annonim, Butanol, http://www.afdc.energy.gov/fuels/emergi ng biobutanol.html, June 12, 2015 (diunduh 2 Nov 2015).

[13] M. Sapp. ASTM sets standard D 78862 for three type of butanol, Biofuels Digest, 9 Oktober (2013).

[14] Gasoline, IARC Monograph, Volume 45, hal 159-201.

[15] P. Kumar, D.M. Barrett, M.J. Delwiche dan P. Stroeve. Methods for Pretreatment of Lignocellulosic Biomass for Efficient Hydrolysis and Biofuel Production. Industrial Engineering and Chemistry Resource 48, 3713-3729 (2009).

[16] J.I. Rahikainan, R.M. Samdero, H. Heikkinen, S. Rovio, K. Marjamaa, T. Tamminen, O.J. Rojas, dan K. Kruus. Inhibitory effect of lignin during cellulose bioconversion : the effect of lignin chemistry on non-productive enzyme adsorption, Bioresources Technology, 133: 270-278 (2013).

[17] H. Wang, M.Tucker dan Y.Ji. Recent development in chemical depolymerization of Lignin: A review, Journal of Applied Chemistry, 13, Article ID 838645 (2013).

[18] N. Mosier, C. Wyman, B. Dale, R. Elander, Y.Y. Lee, M. Holtzapple, dan M. Ladisch. Features of promising technologies for pretreatment of lignocellulosic biomass, Bioresource Technology, 96 : 673-686 (2005).

[19] P. Binod, R. Sindhu, R.R. Singhania, S.Vikram, L.Devi, S.Nagalakshmi, N.Kurien, R.K.Sukumaran, dan A.Pandey. Bioethanol production from rice straw: An overview, Bioresource Technology, 101: 4767-4774 (2010).

[20] H.D. Fajariah dan W Hadi. Pemanfaatan serbuk gergaji menjadi biobutanol dengan hidrolisis selulase dan fermentasi bakteri 
Clostridium Acetobutylicum, Jurnal Teknik Pomits, 3 (2) : F276-280 (2014).

[21] D. Irawan. Produksi biobutanol berbasis sampah organik kota Samarinda sebagai upaya diversifikasi, Politeknik Negeri Samarinda, Penelitian Strategis KemenRistek, 2013.

[22] Fajar. Pengolahan sampah organik kota Makasar menjadi biobutanol sebagai energi terbarukan, Penelitian Hibah Bersaing, Politeknik Negeri Ujung Pandang, 2013.

[23] B. Hasan. Pembuatan bahan bakar alternatif biobutanol dari jerami padi secara fermentasi menggunakan bakteri Clostridium, Penelitian Hibah Bersaing, Politeknik Negeri Ujung Pandang, 2013.

[24] H.Abimanyu dkk. Penelitian konversi energi (PN-8) - Pengembangan pilot plant bioetanol berbasis lignoselulosa sebagai bahan bakar nabati, Laporan Kemajuan Riset Puslit Kimia LIPI, 2012.

[25] N.R. Baral dan A.Shah. Microbial inhibitors: formation and effects on acetone-butanol-ethanol fermentation of lignocellulosic biomass, Applied Microbiol Biotechnol, 98:9151-9172, (2014).

[26] P. Binod, K.U. Janu, R.Sindhu, dan A. Pandey. Hydrolysis of lignocellulose biomass for bioethanol production, dalam Biofuels : Alternatives Feedstock and Conversion Process, Elsevier, chapter 10, 2011, hal 229-250.

[27] A. Procentese, T. Guida, F Raganati, G Olivueri, P Salatino dan A Marzochella. Process simulation of biobutanol production from lignocelulosic feedstocks, Chemical Engineering Transactions, $38:$ 343-348 (2014).

[28] Y. Sun, dan J. Cheng. Hydrolysis of lignocellulosic materials for ethanol production: a review paper. Bioresour. Technol. 83 : 1-11 (2002).

[29] A.I.Yeh, Y.C. Huang, dan S.H. Chen. Effect of particle size on the rate of enzymatic hydrolysis of cellulose,
Carbohydrate Polymers, 79: 192-199 (2010).

[30] Q. Zhang, P. Zhang, Z.J. Pei, dan D. Wang.Relationships between cellulosic biomass particle size and enzymatic hydrolysis sugar yield: Analysis of inconsistent reports in the literature : Review, Renewable Energy, 60 : 127-136 (2013).

[31] X. Zhao, L.Zhang dan D.Liu. Biomass recalcitrance : Part 1 : the chemical compositions and physical structures affecting the enzymatic hydrolysis of lignocelluloses, Biofules, Bioprod.Bioref, $6: 465-482$ (2012).

[32] C.N.Hamelinck, G.V.Hooijdook dan A.P.C. Faaij. Ethanol from lignocellulosic biomass : techno-economic performance in short, middle, and long term. Biomass and Bioenergy, 28(3) : 384-410 (2005).

[33] E.Khullar, B. S. Dien, K.D. Rausch, M.E. Tumbleson, dan V. Singh. Effect of particle size on enzymatic hydrolysis of pretreated Miscanthus, Industrial Crops and Products, 44:11- 17 (2013).

[34] J.Y. Zhu, G.S.Wang, X.J.Pan dan R.Gleisner. Specific surface to evaluate the efficiencies of milling and pretreatment of wood for enzymatic saccharification. Chem Eng Sci. 64:474485 (2009).

[35] B.Lamsal, J. Yoo, K Brijwani dan S. Alvi. Extrusion as a thermo-mechanical pretreatment for lignocelulosic ethanol, Biomass and Bioenergy, 34, Issue 12 :1703-1720, December (2010).

[36] N.Sarkar, S.K.Ghosh, S. Bannerjee dan K. Aikat. Bioethanol production from agricultural wastes : An Overview, Renewable Energy, 37 (99) :19-27 (2012).

[37] V.B. Agbor, N.Cicek, R. Sparling, A. Berlin, dan D.B.Levin. Biomass pretreatment : Fundamentals towards application, Biotechnology Advances, 29: 675-685 (2011).

[38] E. Khullar. DISSERTATION, in Agricultural and Biological Engineering 
in the Graduate College of the University of Illinois at Urbana-Champaign. (2012).

[39] V.S. Chang dan M.T.Holtzapple. Fundamental factors affecting biomass enzymatic reactivity, Applied Biochemistry and Biotechnology, 84: 5-10 (2000).

[40] C.E. Wyman, S.R. Decker dan M.E. Himmel, J.W. Brady, C.E. Skopec, dan L. Viikari. Hydrolysis of Cellulose and Hemicellulose, Chapter 43, Marcel Dekker, 2005.

[41] A.P. Sinitsyn, A.V.Gusakov dan E.Y.Vlasenko. Effect of structural and physico-chemical features of cellulosic substrates on the efficiency of enzymatic hydrolysis, Applied Biochemistry and Biotechnology, 30: 43-47 (1991).

[42] E.K. Bahrin, A.S. Baharudin, M.Z. Ibrahim, M.N.A. Razak, A sulaiman, S.A Aziz, M.A Hassan, Y.Shirai, dan H. Nishia. Physicochemical property changes and enzymatic hydrolysis enhancement of oil palm empty fruit bunches treated with superheated steam, Bioresources, 7 (2) : 1784-1801 (2012).

[43] I.Torrado, F.Bandeira, A.A.Shatalov, F.Carvalheiro dan L.C.Duarte. The impact of particle size on the dilute acid hydrolysis of Giant Reed Biomass, Journal of Energy and Environment 2(1): 1-10, April (2014).

[44] A.H.Mohammed. Disertasi, Technischen Universitat Berlin. (2012).

[45] A.Tesfaw dan F. Assefa. Current trends in bioethanol production by Saccharamyces cerevisiae : Substrate, inhibitor reduction, growth variables, coculture and immobilization, International Scholarly Research Notice, Hindawi Pub Corp., Volume 2014 (2014), article ID 532852, 11 halaman.

[46] J. Li, N.R. Baral dan A.K Jha. Acetonebutanol-ethanol fermentation of corn stover by Clostridium species : Present status and future prospective, World
Journal of Microbulogy Biotechnology, 30:1145-1157 (2014).

[47] W. Jonglertjunya, W. Makkhanon, T. Siwanta dan P. Prayoonyong. Dilute acid hydrolysis of sugarcane bagasse for biobutanol fermentation, Chiang Mai Journal of Science, 41(1), 60-70 (2014).

[48] A. Procentese, T. Guida, F Raganati, G Olivueri, P Salatino dan A Marzochella. Process simulation of biobutanol production from lignocelulosic feedstocks, Chemical Engineering Transactions, 38: 343-348 (2014).

[49] A.L.L. Cesario, A.C da Costa, dan S.C.Rabelo. Effect of particle size on dilute acid pretreatment and enzymatic hydrolysis of sugarcane bagasse, Chemical Engineering Transaction (of AIDIC) 37: 409-414 (2014).

[50] E.K.Bahrin, P.Y. Seng dan S.A. Aziz. Effect of Oil Palm Empty Fruit Bunch Particle Size on Cellulase Production by Botryosphaeria sp. Under Solid State Fermentation, Australian Journal of Basic and Applied Sciences, 5(3): 276-280 (2011).

[51] I. Membrilo, C. Sánchez, M. Menese, E. Favela dan O. Loera. Effect of substrate particle size and additional nitrogen source on production of lignocellulolytic enzymes by Pleurotus ostreatus strains. Bioresour. Technol., 99(16): 7842-7847 (2008).

[52] N. Khienpanya, N Laemsak, S Sirisansaneeyakul, W Vanichsriratana, I.N.Sultan, A.K.TYareen dan P.Parakulsuksatid. Influence of particle size of pretreatment oil palm trunk fibers from simultaneous saccharafication and fermentation on ethanol production, a paper on The $26^{\text {th }}$ Annual Meeting of the Thai Society for Biotechnology and International Conference, 2015.

[53] H.E. Grethlein. The effect of pore size distribution on the rate of enzymatic hydrolysis of cellulosic substrates, Nat.Biotechnology, 3:155-160 (1985). 
[54] S.H.Duque, C.A Cardona dan J.Moncada. Techno-economic and environmental analysis of ethanol production from 10 agroindustrial residues in Columbia, Energy and Fuels, Jan 2015, halaman A-I.

[55] J.A. Quitero, J Moncada, dan C.A.Cardona. Techno-Economic analysis of bioethanol production from lignocellulosic residues in Colombia : A process simulation approach, Bioresource Technology, 139 : 300-307 (2013).

[56] B.C. Vidal, B.S.Dien, K.C.Ting dan V.Singh. The influence of feedstock particle size on lignocelluloses conversions, App.Biochem.Biotechnol 164:1405-1421 (2011).

[57] D. Hamonangan, Chairul dan H.S.Irdoni. Variasi ukuran partikel sorgum pada konversi pati sorgum menjadi bioetanol dengan proses sakarifikasi dan fermentasi serentak, Jurnal FTEKNIK, Universitas Riau, 1(2):1-3, (2014).

[58] D.S. Kamara, S.D. Rachman, dan S.Gaffar. Degradasi enzimatik selulosa dari batang pisang untuk produksi glukosa dengan bantuan aktivitas selulolitik Trichoderma viride, Laporan Penelitian Dasar, Litbang Universitas Pajajaran, 2007

[59] Tim Bioetanol PP Kimia-LIPI. Neraca Material dan Neraca Energi Pembuatan Bioetanol dari TKKS di PP Kimia-LIPI, Laporan Internal Tim, 2015.

[60] H. Lu, E. Ip, J. Scott, P.Foster, M.Vickers dan L.L.Baxter. Effects of particle shape and size on devolatilization of biomass particle. Fuel 89: 1156-1168 (2010). 
J.Kim.Terap.Indones., 18(1),

pp. 11-25, June 2016
p-ISSN: 0853-2788, e-ISSN: 2527-7669 Accreditation number : 540/AU1/P2MI LIPI/06/2013

Halaman ini sengaja dikosongkan

This page intentionally left blank 